Research Article DOI: https://doi.org/10.47434/JEREDA.

eISSN: $2735-9107$

\title{
TEACHING STRATEGY PREFERENCES IN UPPER BASIC SCHOOLS IN ILORIN WEST LOCAL GOVERNMENT AREA, KWARA STATE, NIGERIA
}

\section{${ }^{1}$ Helen B. Victor-Akinyemi, ${ }^{2}$ Elizabeth Obiageli Uyanne, ${ }^{3}$ Judith N. Udeoji, ${ }^{4 *}$ Jumoke I. Oladele}

${ }^{1}$ Federal College of Education, Okene, Nigeria

$2,3,4$ University of Ilorin, Kwara State, Nigeria

1bisfis13@gmail.com; ${ }^{2}$ obynwachi@gmail.com; ${ }^{3}$ udeojisophia@gmail.com

*Corresponding author: ${ }^{4}$ oladele.ji@unilorin.edu.ng

(iD https://orcid.org/0000-0003-0225-7435

Received: $18^{\text {th }}$ August, 2020; Revised: $23^{\text {rd }}$ September, 2020; Accepted: $16^{\text {th }}$ January, 2021

\begin{abstract}
Introduction: Several studies have been carried out on various teaching strategy broadly categorised as teacher-centred, student-centred and student-teacher centred. This study was premised on investigating preferences for these strategies among basic school teachers.
\end{abstract}

Purpose: This study aimed to investigate teacher's teaching strategy preferences in classroom situations in teaching and learning in Upper Basic Classroom situations.

Methodology: The study adopted a descriptive research design of survey type. Teachers in Ilorin West Local Government area of Kwara State constituted the study population while the target population was all Upper Basic school teachers sampled randomly. The instrument used to collect data was a questionnaire tagged "Teachers' Teaching Strategy Preferences Questionnaire" (TTSPQ) which was face and content validated by measurement and evaluation experts. The reliability of the instrument was ascertained using Cronbach's alpha with a reliability index of 0.78 . The validated instrument was administered electronically via Google Forms. Data were analysed using percentages, t-test and ANOVA statistics.

Results: Results showed that teacher-student centred strategy using discussion, demonstration, question \& answer, field trip, and reciprocal methods were preferred while there was a significant difference in teaching strategy preferences based on teaching the subject with Mathematics teachers most contributors to the significance.

Recommendations/Classroom Implications: It was recommended that schools constantly organise training and workshops to better expose all teachers to deploying student-teacher-centred teaching and learning methods.

Keywords: Education, Teaching strategy, Preferences, Classrooms, Upper Basic

Cite paper as:

Crossref Victor-Akinyemi, H. B., Uyanne, E. O., Udeoji, A. N., \& Oladele, J. I. (2021). Teaching strategy preferences in upper basic schools in Ilorin west local government area, Kwara state, Nigeria. Journal of Educational Research in Developing Areas, 2 (1), 1-12. https://doi.org/10.47434/JEREDA.2.1.2021.1.

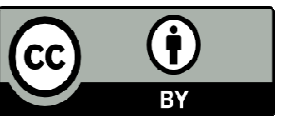

Copyright (c) 2021 The author(s) of this article retain(s) the copyright. 


\section{PUBLIC INTEREST STATEMENT}

Basic education is the education received by children in their formative years. The teaching strategies employed in teaching at this level of education is germane being the foundational phase of education. Empirical research abounds on teaching strategies; however, a lacuna exists between these researches and actual implementation. This study serves as a leeway to the practical use of these strategies in classroom situations relevant for education stakeholders

\section{INTRODUCTION}

Education is known for its role in the knowledge transmission process leading to capacity building of societal members for decades. Nigeria, like other nations of the world, has adopted Universal Basic Education (UBE). Obayan (2004) describes basic education as the level appropriate for building firm roots for literacy, numeracy and inculcating basic life skills while learning how to learn is being consolidated. Yoloye (2004) observed that the Basic Education programme is not completely new to the Nigerian society, however; it has assumed a global significance and its meanings have been broadened. The expanded vision of UBE comprises the universalising of access and promotion of equity, focusing on learning and enhancing the environment of learning and strengthening partnerships.

The 21st century requires equipping children with a basic education in literacy and numeracy, as the more advanced completes skills needed for living that can serve as the foundation of life enables the children to adapt and change life abetting to life's everchanging circumstances. Basic education remains the most important factor that enables the process of enhancing knowledge, skills and attitudes needed for societal and national growth of any country of the world. A child's education starts from the home that is the family (informal education) and proceeds to nursery school, primary school, secondary school, and tertiary level of formal education (Owolabi \& Olorunlero, 2011).

Saddled with the responsibility of implementing the curriculum are teachers being a major role. Recognising the role of teachers in the implementation of the National Policy on Education, Chukwuemeka (2014) reiterated that Volume 2, Number 1 teachers hold the key for unlocking the door to modernisation through teaching and learning and this is only achievable when teachers acquire the needed competencies in terms of knowledge, skills, values and attitudes. Implied is that no nation can rise above the quality of its teachers, especially at the basic education level being the bedrock of the educational system.

According to Kymet (2010), competent teachers are the most critical element in improving student achievement and closing the achievement gap. The important difference between the most and least effective classrooms is the teacher. The single most important influence on student learning is the quality of teaching. If teachers are not given the opportunities to improve classroom practices, it is the student's achievement that may be harmed as a result. Tucker and Stronge (2005) stated that research on teacher quality supports the fact that effective teachers make students feel good about school and learning and that their work results in increased student achievement. Studies have shown that a whole range of personal and professional qualities are associated with higher student achievement levels. For example, research has shown that verbal ability, content knowledge, pedagogical knowledge, certification status, ability to use a range of teaching strategies skillfully, and enthusiasm for the subject characterise more successful teachers.

Teaching is a change-driven activity through the use of appropriate methods (Ayeni, 2011) and to bring desirable changes in students, best suiting methods to subject matter should be employed (Adunola, 2011). Mulligan (2011) pointed out that effective teaching requires 'flexibility and creativity, constant monitor and 
adjustment' of the teaching techniques. On the other hand, Knutson (2014) pointed out that choosing the appropriate approaches in teaching and how these approaches are made is pertinent to students' learning. Bay (2013) maintained that the teaching strategy's success depends on the frequency of its use in the classroom. Oladele, Akano, Joseph and Owolabi (2019) reiterated that teaching effective does involve the utilisation of tools, techniques, and strategies and the comprehension of meanings specifically on how students learn, process information, motivates themselves, and the things which hinder learning.

Teaching can be approached as teacher-centred, student-centred or teacher-student centred. Teachers are the major drivers of the teaching and learning process with the teacher-centred approach, while students are passive listeners (Boud \& Feletti, 1999). This approach is more theoretical and characterised by a high level of memorisation with less room for practicability (Teo \& Wong, 2000) and mostly used by teachers (Oladele et al., 2019). A major disadvantage with this approach is that students risk losing interest and understanding of subject matter. To address such shortfalls, teachers should give room for students engagement to actively engage them in their learning (Zakaria, Chin \& Daud, 2010).

This point to discovery learning proved to enhance active students' learning while promoting interest, analytical research, critical thinking, and enjoyment (Greitzer, 2002; Hesson \& Shad, 2007). This method's effectiveness is attributed to decentralising the flow of knowledge from the lecturer to the student while ensuring goal-orientated behaviour among students with the resultant effect on students' achievement (Damodharan \& Rengarajan, 1999).

Engaging various instructional methods helps engage students in the learning process, such as self-directed learning, cooperative learning, roleplaying, and technology (Driscoll, 2005). With self-directed learning strategy, Volume 2, Number 1 students engage their imaginative and intuitive capacities (Borich, 2011). Cooperative learning strategies are a collection of instructional methods appropriate for small groups of students working together to gain from each other and maximise learning. As such, a method that fails with one student may be beneficial to another, which enables the achievement of stated behavioural objectives (Ikwumelu \& Oyibe, 2011; Nnamdi \& Oyibe, 2016). They further explained that the utilisation of individualised instructional methods enables students' self-paced learning. This study focused on the Teachers' teaching strategy References in Upper Basic Classroom Situation schools in Ilorin South Local Government.

\section{STATEMENT OF THE PROBLEM}

Teachers have a profound effect on students, and the school systems make a significant long-term investment when teachers are hired. Unlike other education investments, such as class size, which may easily be altered from year to year, the tenure system implies that an individual teacher's employment is near permanent. For these reasons, the selection of strategies employed by the teacher in teaching and learning is of paramount importance (Wegner, Minnaert \& Strehlke 2013; Ayua, 2017). Several studies are available on the importance of teaching/learning aids or resources, but a few on the teaching strategy preferences in a classroom and whether teachers effectively use these teaching/learning strategies. It is on this premise that this study aims to examine the Teacher's Teaching Strategy preferences in Upper Basic Classroom Situations.

\section{PURPOSE OF THE STUDY}

The purpose of this study is to investigate teachers' teaching strategy preferences in classroom situations in teaching and learning in Upper Basic Classroom Situations. The specific purposes were to determine the: 


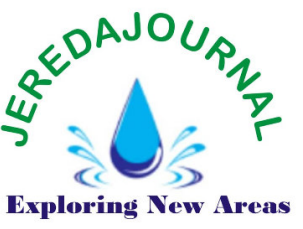

1. teachers' preferred teaching strategy for teaching and learning in Upper Basic Schools in Ilorin West Local Government Area; and

2. differences in teaching strategies preferred by Upper Basic Schools teachers in Ilorin West Local Government Area based on gender, year of experience, qualification, and school type.

\section{RESEARCH QUESTION}

What is the most preferred teachers' teaching strategy for teaching and learning in Upper Basic Schools in Ilorin West Local Government Area?

\section{HYPOTHESES}

1. There is no significant difference in teachers' teaching preferences for teaching in Upper Basic schools Ilorin West Local Government Area based on gender.

2. There is no significant difference in teachers' teaching preferences in Upper Basic schools in Ilorin West Local Government Area based on year of experience.

3. There is no significant difference in teachers' teaching preferences in Upper Basic schools in Ilorin West Local Government Area based on qualification.
4. There is no significant difference in teachers' teaching preferences in Upper Basic schools in Ilorin West Local Government Area based on School type (public/private).

\section{METHODOLOGY \\ Research Designs}

The study adopts the descriptive research design of survey type appropriate for describing behaviours by gathering people's perceptions, opinions, attitudes, and beliefs about a current issue (Ponto, 2015).

\section{Population and Sample}

The study population is all public and private secondary schools in Ilorin West Local Government. The target population for the study was Upper Basic School Teachers in Ilorin West. The population of public and private schools in Ilorin West is 50, with 30 public schools and 20 private schools (Ministry of Education, Ilorin, 2015/2016). Sampling Technique employed for the study was a multi-stage sampling (stratified and cluster sampling). The population was divided into two Strata (public and private schools) and then cluster sampling was used to make the needed selection of units in the different strata. Shown in Tables 1 to are the demographic representation of study participants. 
Journal of Educational Research in Developing Areas (JEREDA)

Vol. 2. Issue 1, Pp. 1-12, 2021

http://www.jeredajournal.com

E-mail: info@jeredajournal.com

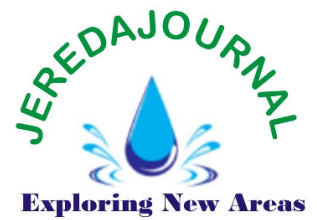

Table 1: Distribution of Participants by Gender

\begin{tabular}{|c|c|c|c|}
\hline Variable & & Frequency & $\begin{array}{l}\text { Per cent } \\
(\%)\end{array}$ \\
\hline \multirow[t]{3}{*}{ Gender } & Male & 35 & 42.7 \\
\hline & Female & 47 & 57.3 \\
\hline & Total & 82 & 100.0 \\
\hline \multirow[t]{4}{*}{$\begin{array}{l}\text { Highest } \\
\text { Qualification }\end{array}$} & $\begin{array}{l}\text { Bachelor of Science } \\
\text { (Education) }\end{array}$ & 27 & 32.9 \\
\hline & Bachelor of Science & 54 & 65.9 \\
\hline & Masters & 1 & 1.2 \\
\hline & Total & 82 & 100.0 \\
\hline \multirow[t]{13}{*}{ Teaching Subject } & Economics & 13 & 15.9 \\
\hline & Geography & 13 & 15.9 \\
\hline & Social Studies & 2 & 2.4 \\
\hline & English Language & 25 & 30.5 \\
\hline & Finance & 3 & 3.7 \\
\hline & Mathematics & 4 & 4.9 \\
\hline & Biology & 2 & 2.4 \\
\hline & Agricultural Science & 4 & 4.9 \\
\hline & $\begin{array}{l}\text { Other Languages (Yoruba and } \\
\text { French) }\end{array}$ & 2 & 2.4 \\
\hline & Chemistry & 3 & 3.7 \\
\hline & Physics & 3 & 3.7 \\
\hline & $\begin{array}{l}\text { Others (Music, Basic tech, } \\
\text { Comp sci., Fine arts, } \\
\text { Commerce, Literature, Govt.) }\end{array}$ & 8 & 9.8 \\
\hline & Total & 82 & 100.0 \\
\hline \multirow[t]{4}{*}{ Experience } & 5-10 Years & 52 & 63.4 \\
\hline & $11-15$ Years & 22 & 26.8 \\
\hline & 16 Years and above & 8 & 9.8 \\
\hline & Total & 82 & 100.0 \\
\hline
\end{tabular}

As shown in Table 1, 35(42.7\%) of the teachers were males, while $47(57.3 \%)$ were females. This shows that more female teachers participated in the study than males. Concerning highest qualification of respondents, $27(32.9 \%)$ of the respondents held Bachelor of Science degree with education, $54(65.9 \%)$ held bachelor of Science degree with no education while $1(1.2 \%)$ of the respondents had Master's Degree in Education. This shows that most of the teachers were unqualified teachers with no training in teaching pedagogy. Furthermore, on respondents' teaching subjects, $13(15.9 \%)$ of the respondents were qualified in Economics and Geography each, $2(2.4 \%)$ in Social Studies, Biology and Other Languages (Yoruba and French) each, 25(30.5\%) in the English Language, 3(3.7\%) in Finance, Chemistry and Physics each, $4(4.9 \%)$ in Mathematics and Agricultural Science each, Biology and Chemistry respectively while $8(9.8 \%)$ in Other subjects (Music, Basic tech, Comp sci., Fine arts, Commerce, Literature, 
Govt.) This shows that most of the teachers were qualified in the English Language. Lastly, on participants years teaching experience, $22(26.8 \%)$ eleven to fifteen years while $8(9.8 \%)$ had 16 and above years of experience. This shows that most of the teachers had between five to ten years of experience.

\section{Instrument for Data Collection}

The instrumentation used is the Teachers' Teaching Strategy Preferences Questionnaire (TTSPQ). The TTSPQ was divided into 2 sections. Section A (demographic profile of the respondents), section $B$, (preferred teaching strategies). Section B was on a 3 Point Scale of Preferred (P), Slightly Preferred (SP) and Not Preferred (NP). Section A of the questionnaire sought information on the teachers' personal data such as gender, school type, years of experience, and academic qualification. Section $B$ was concerned with gathering information on the relevant items on teachers' preference for teaching strategies. TTSPQ was subjected to face and content validity by an expert in educational research from the Department of Social Studies Education, Faculty of Education, University of Ilorin, Ilorin, Nigeria. The expert review and comments were effected to the final draft for the study. The reliability of the instrument was ascertained using Cronbach's alpha method. A Cronbach's alpha coefficient of 0.75 was obtained, showing that the instrument was reliable.

\section{Procedure of Data Analysis}

Although the long-standing paperpencil survey questionnaires continue to be the main mode of data collection, web-based surveys are gradually gaining popularity for research. The researcher obtained a letter of introduction from the Head of Department of Social Sciences Education with which the school principals were approached to collect the teachers' WhatsApp phone numbers using a Phone Number Collation Form. Afterwards, a WhatsApp Group was created by the researcher, and all collated contacts were added. The instrument was deployed electronically through the use of Google forms, and the link to the form was disseminated via the Whatsapp Group created.

\section{Method(s) of Data Analysis}

The data were analysed using descriptive statistics of percentages, mean and standard deviation with which the study research questions were answered. The generated study hypotheses were tested using inferential statistics (t-test and ANOVA).

\section{RESULTS}

Research Questions 1: What is the most preferred teaching strategy and learning in Upper Basic Schools in Ilorin West?

To answer research question one, responses were analysed using descriptive statistics of percentages. The first strategy was the most preferred strategies for teaching and learning, as shown in Table 2.

Table 2: Preferred strategies for teaching and learning

\begin{tabular}{lcc}
\hline Strategies & $\begin{array}{c}\text { Percentag } \\
\mathbf{e}(\%)\end{array}$ & Rank \\
\hline student-centred (Roleplay, project, problem-solving, & 67.53 & $2^{\text {nd }}$ \\
Inquiry) & & \\
teacher-centred (Lecture, Simulation, Direct teaching) & 65.47 & $3^{\text {rd }}$ \\
Teacher-Student Centered (Discussion, Demonstration, & 78.56 & $1^{\text {st }}$ \\
Q/A, Field trip, reciprocal) & & \\
\hline
\end{tabular}


As shown on table 2, with a percentage of $78.56 \%$ which ranked first, teacherstudent centred strategy using discussion, demonstration, question and answer, field trip, and reciprocal methods were the most preferred for teaching and learning.
Hypothesis 1: There is no significant difference in teaching strategy preferences in Ilorin West Local Government Area based on teachers' gender.

Hypothesis one was tested using t-test statistics, as shown in Table 3.

Table 3: T-test summary on significance in male and female teachers' teaching strategy preferences

\begin{tabular}{lllcllll} 
Gender & N & Mean & $\begin{array}{c}\text { Std. } \\
\text { Deviation }\end{array}$ & df & Cal. t & $\begin{array}{c}\text { P- } \\
\text { value }\end{array}$ & Decision \\
\hline Male & 35 & 28.97 & 4.409 & & & & \\
& & & 80 & 1.143 & .26 & Do not reject
\end{tabular}

Female $\quad 47 \quad 27.74 \quad 5.084$

As shown in Table 3, t calculated value is 1.143 significant at the 0.05 alpha level. The null hypothesis one is not rejected since the P-value .26 is greater than 0.05 alpha level $(0.26>0.05)$. Thus, the null hypothesis states that no significant

difference in teaching strategy preferences based on teachers' gender is not rejected. Therefore, it means that male and female teachers do not differ in their teaching strategy preferences for teaching and learning in Upper Basic schools in Ilorin West Local Government, Kwara state.

Hypothesis 2: There is no significant difference in teaching strategy preferences in Ilorin West Local Government Area based on teachers' qualification.

Hypothesis two was tested using t-test statistics, as shown in Table 4.

Table 4: T-test summary of differences in B.Sc. and B.Sc. (Ed.) teachers' teaching strategy preferences

\begin{tabular}{llccccc}
\hline Qualification & $\mathbf{N}$ & Mean & $\begin{array}{c}\text { Std. } \\
\text { Deviation }\end{array}$ & df & Cal. t & P-value Decision \\
\hline B.Sc. & 54 & 27.56 & 2.803 & &
\end{tabular}

$\begin{array}{llll}79 & 1.844 & .01 & \text { Reject }\end{array}$

B.Sc. (Ed.) $\quad 27 \quad 29.63 \quad 5.486$

As shown in Table 4, $\mathrm{t}$ calculated value is 1.844 significant at the 0.05 alpha level. The null hypothesis one is rejected since the P-value .01 is less than 0.05 alpha level $(0.01<0.05)$. Thus, the null hypothesis states that no significant difference in teaching strategy preferences based on teachers' qualification is rejected. Therefore, it means that qualified and non-qualified Volume 2, Number 1 teachers differ in their teaching strategy preferences for teaching and learning in Upper Basic schools. With a higher mean of 29.63, qualified teachers with B.Sc. (Education degrees) brought about the significance.

Hypothesis 3: There is no significant difference in teaching strategy preferences in Ilorin West Local 
Journal of Educational Research in Developing Areas (JEREDA)

Vol. 2. Issue 1, Pp. 1-12, 2021

http://www.jeredajournal.com

E-mail: info@jeredajournal.com

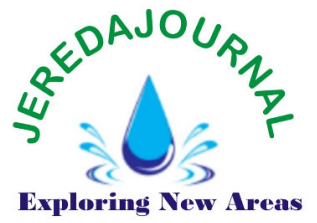

Government Area based on teachers'

Hypothesis three was tested

teaching subject.

using Analysis of Variance (ANOVA)

statistics, as shown in Table 5.

Table 5: ANOVA summary on differences in teachers' teaching strategy preferences based on teaching subject

\begin{tabular}{lcccccc}
\hline & $\begin{array}{c}\text { Sum of } \\
\text { Squares }\end{array}$ & df & $\begin{array}{c}\text { Mean } \\
\text { Square }\end{array}$ & F & P & \\
\hline Between Groups & 447.257 & 11 & 40.660 & 1.986 & .04 & Reject \\
Within Groups & 1432.841 & 70 & 20.469 & & & \\
Total & 1880.098 & 81 & & & & \\
& & & & & & \\
\hline
\end{tabular}

Table 5 shows F-value of 10.340 significant at 0.05 level of significance and $p$-value of 0.04 . Since the $p$-value 0.04 is less than 0.05 alpha level $(0.04<$ $0.05)$, hypothesis stating that there is no significant difference in teaching strategy preferences in Ilorin West based on teachers' teaching subject is rejected.
Therefore, it means that different subject teachers do not differ in their

teaching strategy preferences for teaching and learning in Upper Basic schools in Ilorin West LGA. Duncan's Post hoc test was carried out to find the different sources, as shown in Table 6.

Table 6: Duncan's post hoc table on where the difference in teaching strategy preferences lies

\begin{tabular}{lccc}
\hline \hline & \multicolumn{4}{c}{ Subset for alpha $=\mathbf{0 . 0 5}$} \\
TESCHINGSUBJECT & $\mathbf{N}$ & $\mathbf{1}$ & $\mathbf{2}$ \\
\hline Other languages (Yoruba and French) & 2 & 24.0000 & \\
Economics & 13 & 24.6923 & 24.6923 \\
Finance & 3 & 25.3333 & 25.3333 \\
Agricultural Science & 4 & 26.0000 & 26.0000 \\
Geography & 14 & 27.8571 & 27.8571 \\
Others (Music, Basic tech, Comp sci., & 7 & 27.8571 & 27.8571 \\
Fine arts, Commerce, Literature, Govt.) & & 29.0000 & 29.0000 \\
Biology & 2 & 29.6667 & 29.6667 \\
Physics & 3 & 30.2000 & 30.2000 \\
English Language & 25 & 30.3333 & 30.3333 \\
Chemistry & 3 & 30.5000 & 30.5000 \\
Social Studies & 2 & & 32.5000 \\
Mathematics & 4 & .113 & .055 \\
Sig. & \multicolumn{4}{l}{} \\
Means for groups in homogeneous subsets are displayed. & \\
\hline
\end{tabular}


As shown in Table 6, teachers with Mathematics as their teaching subjects had the highest mean of 32.50, followed by social studies, Chemistry, English Language, Physics,

Biology, others, Geography, Agricultural Science, Finance, and Economics in the same subset with means of 30.50 , $30.33,30.20,29.67, \quad 29.00$, $27.86,27.86,26.00,25.33$, and 24.69 respectively and then Yoruba and French languages with a mean of 24.00.
This shows that teachers with Mathematics as their teaching subject with mean scores of 32.50 brought about the significance.

Hypothesis 4: There is no significant difference in teaching strategy preferences in Ilorin West Local Government Area based on teachers' years of experience.

Hypothesis 4 was tested using Analysis of Variance (ANOVA) statistics, as shown in Table 7.

\section{Table 7: ANOVA summary on differences in teachers' teaching strategy preferences based on years of experience}

\begin{tabular}{lcccccc}
\hline & $\begin{array}{c}\text { Sum of } \\
\text { Squares }\end{array}$ & df & $\begin{array}{c}\text { Mean } \\
\text { Square }\end{array}$ & F & P & Decision \\
\hline $\begin{array}{l}\text { Between } \\
\text { Groups }\end{array}$ & 36.998 & 2 & 18.499 & .793 & .46 & Do not Reject \\
Within & 1843.100 & 79 & 23.330 & & & \\
Groups & 1880.098 & 81 & & & & \\
Total & & & & & & \\
\hline
\end{tabular}

Table 7 shows a calculated Fvalue .793 significant at 0.05 alpha level and $p$-value of 0.46 . Since calculated significance 0.46 greater than 0.05 alpha level (0.46>0.05), hypothesis stating that there is no significant difference in teaching strategy preferences in Ilorin West based on teachers' years of experience is not rejected. Therefore, it means that teachers irrespective of their years of teaching experience do not differ in their teaching strategy preferences for teaching and learning in Upper Basic schools in Ilorin West LGA.

\section{DISCUSSIONS}

This study's findings revealed that qualified and non-qualified teachers differ in their teaching strategy preferences for teaching and learning in Upper Basic schools in Ilorin West LGA. This finding is in line with that of Hanushek (2000) surveyed the 113 studies on the impact of teachers' qualifications on their Volume 2, Number 1 students' academic achievement. Eightyfive per cent of the studies found no positive correlation between the students' educational performance and the teacher's educational background. Although 7 per cent of the studies did find a positive correlation, 5 per cent found a negative impact, one of the main findings concerning teacher qualifications has been the relatively high incidence of teachers teaching subjects outside their areas of subject-matter training and certification (Ingersoll, 2000).

This study also revealed that teacher-student centred strategy also known as the mid-way approach using discussion, demonstration, question\& answer, field trip, and reciprocal methods were the most preferred for teaching and learning in Upper Basic schools in Ilorin West Local Government, Kwara State. This is due to the importance of the midway approach being regarded as more effective due to the decentralised 
knowledge flow. It also motivates goalorientated behaviour among students; hence the method is very effective in improving student achievement. Applying student-centred approaches promotes interest, critical thinking, and maximum students' engagement and enjoyment (Hesson \& Shad, 2007). Also, a study carried out by Okoye, Aigbomian and Okecha (2008) show that combined variables of teacher quality and instructional strategies are correlated with achievements.

Finally, the study showed that teachers irrespective of their years of teaching experience do not differ in their teaching strategy preferences for teaching and learning in Upper Basic schools in Ilorin West LGA. A more recent analysis by Wenglinsky (2000) used multilevel structural equation modelling to analyse data from the NAEP and found that teachers with a major or minor in the subject area assigned to teach produce greater gains in student achievement.

\section{CONCLUSION}

Based on this study's findings, it was concluded while teachers preferred student-teacher centred strategy for teaching; Mathematics was better disposed to using student-teacher centred strategy for teaching and learning.

\section{RECOMMENDATIONS}

Based on the results of data study and tested hypothesis, it is hereby recommended that:

1. The teachers should put in more efforts to incorporate all teaching strategies in teaching and learning.

2. Schools should constantly organise training and workshop to better expose all teachers to deploying student-teacher centred methods.

Conflicts of Interest: The authors declare no conflict of interest.

Volume 2, Number 1

\section{Acknowledgements}

Due acknowledgement is given to the principals and staff of all schools that participated in the study for the maximal cooperation received at the datagathering stage of the study.

\section{Disclaimer Statement}

We hereby declare that this paper is our own and autonomous work. All sources and aids used have been indicated as such. All texts either quoted directly or paraphrased have been indicated by in-text citations. Full bibliographic details are given in the reference list, which also contains internet sources containing URL and access date. This work has not been submitted to any other examination authority.

\section{Notes on Authors}

Helen, B. VICTOR-AKINYEMI holds a Senior Lecturer position at the Department of Curriculum and Instruction, Federal College of Education, Okene, Kogi State. She is currently undergoing her PhD in Curriculum Development. Research Interest: curriculum development in economics and teaching methodologies and teacher education

Elizabeth O. UYANNE holds a Lecturer I position at the Department of Social Sciences Educational, the University of Ilorin with specialisation in Educational Psychology. Research Interest: teaching and learning styles and teacher education Judith N. Udeoji is a graduate student of the Department of Social Sciences Educational, the University of Ilorin. Research interest: teaching methodologies and teacher education.

Jumoke, I. OLADELE holds Lecturer II position at the Department of Social Sciences Educational, the University of Ilorin with specialisation in Educational Research, Measurement and Evaluation. She holds the membership of learned societies nationally and internationally and currently a Postdoctoral research fellow at the University of Johannesburg, South Africa. Research Interest: innovation in educational assessments, teaching/learning and teacher education 


\section{Authorship and Level of Contribution} 'HBA' validated the instrument, 'EOU' proofread the manuscript, 'JNU' gathered the data for the study while 'JIO' analysed/interpreted the data, prepared the manuscript and subjected manuscript to plagiarism test. All authors perused and approved the final manuscripts.

\section{REFERENCES}

Adunola, O. (2011). The impact of teachers' teaching methods on the academic performance of primary school pupils in Ijebu-Ode local cut area of Ogun State. Ego Booster Books.

Ayeni, A. J. (2011). Teachers professional development and quality assurance in Nigerian secondary schools. World Journal of Education, 1(2), 143-149.

Bay Jr, B. E. (2013). Integration of technology-driven teaching strategies for enhancing Photo journalism Course. Educational Research International, 2(2), 155164.

http://www.erint.savap.org.pk/PD F/Vol.2(2)/ERInt.2013(2.2-19).pdf

Boud, D., \& Feletti, G. (1999). The challenge of problem-based learning,(2nd Ed.). Kogan Page.

Ayua, G. A. (2017). Effective teaching strategies. Paper presented at Orientation and Refresher Workshop for Teachers. https://doi.org/10.13140/RG.2.2.3 4147.09765.

Borich, G. D (2011). Effective teaching methods, research-based practice (7th ed.). Pearson Education, Inc.

Chukwuemeka, F. C. (2014). Evaluation of the implementation of the social studies curriculum in junior secondary schools in Enugu state. Unpublished Masters Dissertation, University of Nigeria, Nsukka.

Driscoll, M. P. (2005). Psychology of learning for instruction (3rd ed). Pearson.

Damodharan, V. S., \& Rengarajan, V. (1999). Innovative methods of teaching. National Research

Volume 2, Number 1
Council, Educational Journal Publication.

Greitzer, F. A. (2002). Cognitive approach to student-centered elearning, human factors and society. 46th Annual Meeting, Sept $30 \quad-\quad$ Oct 4. http://availabletechnologies.pnnl.g ov/media/33 97200670001.pdf

Goldhaber, D. (2002). The mystery of good teaching: Surveying the evidence on student achievement and teachers' characteristics. Hoover Institution. http://www.hoover.org/publication s/ednext/3368021.html

Hesson, M., \& Shad, K. F. (2007). A student-centred learning model. American Journal of Applied Sciences, 4 (9), 628-636.

Ikwumelu, S. N., \& Oyibe, O. A. (2011). Effective delivery of Social studies curriculum content for peace and cooperative living in Nigeria. Journal of Arts and Social Science Education, 2(1), 265-273.

Ingersoll, R. (2000). Rejoinder: Misunderstanding the problem of out-of-field teaching.

Educational Researcher 30 (1), 2122.

Knutson, S. (2014). Teaching strategies used by effective teachers. http://www.homepages.dsu.edu/m olstadl/SDBEA/vars02/article7.htm

Kymet, S. (2010). Teachers' competencies. International Journal of Philosophy of Culture and Axiology (online), 7(1), 167-175.

Ministry of Education, (2015/2016). Population census in Ilorin metropolis secondary school, Kwara state.

Mulligan, E. (2011). What works: Effective teaching strategies for students with disabilities.

http://nichcy.org/what-workseffective-teaching-strategies-forstudents with-disabilities

Nnamani, S. C., \& Oyibe, O. A. (2016). Effects of individualised instructional method on secondary school students' achievement in social studies. 


\section{British Journal of Education,} $4(3), 110-120$.

Obanya, P. (2004). The Dilemma of Education in Africa. Ibadan: Heinemann Educational Books.

Okoye, N. S., Momoh, S. O., Aigbomian, D. O., \& Okecha, R. E (2008). Teachers' quality, instructional strategies and students' performance in secondary school science. Journal of Instructional Psychology 34 (4), 204-211.

Oladele, J. I., Akano, O. T., Joseph, M. H., \& Owolabi, H. O. (2019). Impact of innovative teaching method on secondary school students' academic performance in economics in ilorin metropolis. Journal of Educational Research and Development, 6,115-125.

Owolabi, H. O., \& Olorunlero, J. I. (2011). A survey of basic education skills demonstrated by final year junior secondary school students' in Kabba/Bunu LGA. Nigerian Journal of Educational Foundation, 10 (1), 31-39. http://ejournals.unilorin.edu.ng/jo urnals/index.php/nijef/issue/view/ 64/owola bi2

Ponto, J. (2015). Understanding and evaluating survey research. Journal of the advanced Practitioner in Oncology, 6(2), 168 $-175$.

Teo, R., \& Wong, A. (2000). Does problem based learning create a better student: a reflection? paper presented at the 2nd Asia Pacific conference on problem based learning: Education across disciplines. 4th to 7th December, Singapore.

Tucker, P. D., \& Stronge, J. H. (2005). Linking teacher evaluation and student learning. Association for Supervision and Curriculum Development (ASCD).

Wegner, C., Minnaert, L., \& Strehlke, F. (2013). The importance of learning strategies and how the project" kolumbus-kids" promotes them successfully. European Journal of Science and Mathematics Education, 1(3), 137-143.

https://files.eric.ed.gov/fulltext/E] 1108220.pdf

Wenglinsky, H. (2000). Teaching the teachers: Different settings, different results. Educational Testing Service.]

Yoloye, A. E. (2004). The relevance of universal basic education in the development of primary education system in Nigeria. In T. L. Adepoju (Ed.), Planning and implementation of universal basic education in Nigeria education. Industries Nigeria Limited.

Zakaria, E., Chin, C. L., \& Daud, Y. (2010). The effect of cooperative learning on student mathematics achievements and attitude towards mathematics. Journal of Social Sciences, 6(2), 272-275. https://doi.org/10.3844/jssp.2010 .272 .275 . 